This document is the accepted manuscript version of the following article: Batlle-Aguilar, J., Brovel1i, A., Luster, J., Shrestha, J., Niklaus, P. A., \& Barry, D. A. (2012). Analysis of carbon and nitrogen dynamics in riparian soils: model validation and sensitivity to environmental controls. Science of the Total Environment, 429, 246-256.

https://doi .org/10.1016/j.scitotenv.2012.04.026

\title{
Analysis of carbon and nitrogen dynamics in riparian soils:
}

\section{Model validation and sensitivity to environmental controls}

J. Batlle-Aguilar $^{1,4}$, A. Brovelli $^{1 *}$, J. Luster ${ }^{2}$, J. Shrestha $^{2}$, P.A. Niklaus ${ }^{3}$, D.A. Barry ${ }^{1}$

${ }^{1}$ Ecological Engineering Laboratory, Institute of Environmental Engineering, Faculté de

l'Environnement Naturel, Architectural et Construit (ENAC), École Polytechnique Fédérale de

Lausanne (EPFL), Station 2, 1015 Lausanne, Switzerland (alessandro.brovelli@epfl.ch,

andrew.barry@epfl.ch)

${ }^{2}$ Soil Structure and Function Group, Swiss Federal Research Institute (WSL), 8903 Birmensdorf,

Switzerland (joerg.luster@wsl.ch, juna.shrestha@wsl.ch)

${ }^{3}$ Institute of Evolutionary Biology and Environmental Studies, University of Zürich, 8057 Zürich,

Switzerland(pascal.niklaus@ieu.uzh.ch)

${ }^{4}$ Now at National Centre for Groundwater Research and Training (NCGRT), School of the

Environment, Flinders University, GPO Box 2100, Adelaide, South Australia 5001, Australia

(jordi.batlleaguilar@flinders.edu.au)

Accepted for publication in Science of the Total Environment

9 April 2012

\footnotetext{
* Corresponding author, ph.: +41 (0) 2169359 19, fax: +41 (0) 216938035
} 


\begin{abstract}
1 Abstract
2 The Riparian Soil Model (RSM) of Brovelli et al. (2012) was applied to study soil 3 nutrient turnover in a revitalized section of the Thur River, North-East Switzerland. In 4 the present work, the model was calibrated on field experimental data, and 5 satisfactorily reproduced soil respiration, organic matter stocks and inorganic nitrogen 6 fluxes. Calibrated rates were in good agreement with the ranges reported in the 7 literature. The main discrepancies between model and observations were for dissolved 8 organic carbon. The sensitivity of the model to environmental factors was also

9 analysed. Soil temperature was the most influential factor at daily and seasonal scales 10 while effects of soil moisture were weak overall. The ecosystem sensitivity to 11 temperature changes was quantified using the Q10 index. The seasonal behaviour 12 observed was related to the influence of other forcing factors and to the different state 13 (density and activity) of the microbial biomass pool during the year. Environmental 14 factors influencing microbial decomposition, such as the $\mathrm{C}: \mathrm{N}$ ratio and litter input 15 rate, showed intermediate sensitivity. Since these parameters are tightly linked to the 16 vegetation type, the analysis highlighted the effect of the aboveground ecosystem on 17 soil functioning.
\end{abstract}

18 Keywords: Ecological restoration; Riparian landscape; Nutrient cycles; Ecological

19 Modelling; DOC mobilization; $\mathrm{N}$ removal 


\section{Introduction}

21 Riparian zones are dynamic boundaries between terrestrial and aquatic systems, and play a paramount role in maintaining the vitality of landscapes and of surface water bodies (Naiman et al., 2000; Naiman and Décamps, 1997). These zones have key ecological functions: They act as ecological corridors and help preserve biodiversity in urban and industrialized environments (Goodwin et al., 1997; Martin and Chambers, 2002). Moreover, they have the ability to filter and clean-up polluted waters, preserving natural and healthy ecosystems. However, riparian zones are varied and not all function for instance as filters for polluted waters with the same effectiveness. For example, nitrate attenuation in riparian woodlands is significantly more effective than riparian grasslands (Lyons et al., 2000; Mayer et al., 2005), although their effectiveness was found to be lower in phosphate and dissolved organic phosphorous removal (Osborne and Kovacic, 1993). Nitrate is stored in biota via plant root uptake and microbial immobilization or converted to gaseous $\mathrm{N}_{2}$ and nitrous oxide $\left(\mathrm{N}_{2} \mathrm{O}\right)$ and removed via microbial denitrification (Klocker et al., 2009; Mander et al., 2005; Prober et al., 2005; Torok et al., 2000). Forest vegetation generally provides more organic matter in deeper subsoils than grassed lands, which is needed for effective denitrification in groundwater (Correll, 1997). Degradation of riparian woods engenders a loss of potential nitrate removal effectiveness.

Despite their importance, in the last century riparian areas were often profoundly modified and degraded, with a significant loss of ecological significance and functioning (Richardson et al., 2007). The trend has changed in recent years, with the design and implementation of a number of restoration projects, with the aim to re-establish the original natural status and conditions (Young et al., 2005). As a part of restoration design and for the assessment of the improved ecological status, numerical tools have been increasingly used to understand and forecast the modifications induced in ecosystems because of changes in land use, climatic 
parameters and management practices. Predictive models of soil organic matter (SOM) evolution include soil carbon (C) and $\mathrm{N}$ fluxes and their coupled dynamics. Numerous SOM models exist (Manzoni and Porporato, 2009), although only a few of them have been specifically developed, or adapted, to evaluate changes in ecosystem functioning in riparian areas (e.g.: SWIM, Hattermann et al., 2004; TNT2, Oehler et al., 2009).

Dissolved organic matter (DOM), which includes dissolved organic C (DOC) and N (DON), is an important controlling factor for the ecological functioning of forest soils (Michalzik et al., 2003) and grasslands (Kindler et al., 2011), as well as a major C source to mineral soils. For these reasons, their fate and dynamics are crucial for the prediction of organic $\mathrm{C}$ pools (Neff and Asner, 2001), in particular in riparian strips, which are influenced by the adjacent river and can have large external DOM inputs. The latter can occur, for example, during flood events, when unstructured soil material with labile organic matter is deposited (Samaritani et al., 2011). Despite their importance, DOM dynamics are frequently not accounted for when modelling soil nutrient turnover.

Within the soil, organic $\mathrm{C}$ is transferred between different pools by means of decomposition processes mediated by pedofauna. The activity of micro-organisms is regulated by environmental conditions, mainly soil moisture and temperature (Brady and Weil, 2004). The soil surface temperature signal is quickly dampened with depth and, at a depth of about $1 \mathrm{~m}$, temperature variations are negligible compared with soil moisture changes (Rodriguez-Iturbe and Porporato, 2004). This argument has been used to explain partially the higher influence of soil moisture on microbial activity, in particular in dry environments (Bell et al., 2008;

Davidson et al., 1998; Koch et al., 2007; Rodriguez-Iturbe and Porporato, 2004). Temperature changes at the daily and seasonal scales can result in topsoil temperature variations up to 5$10^{\circ} \mathrm{C}$. Since the upper part of the soil profile is where $\mathrm{OM}$ is more abundant, in this shallow zone temperature is likely to have a large influence on microbial activity and C fluxes. The 
relationship between soil respiration (i.e., $\mathrm{CO}_{2}$ emissions from a soil profile) and temperature has been investigated thoroughly. In this context, the parameter Q10, which indicates the increase in soil respiration for a $10^{\circ} \mathrm{C}$ increase in soil temperature, has been used to compare the sensitivity of different ecosystems (Beier et al., 2008). In well-drained, water-rich ecosystems, where moisture availability is seldom or never a limiting factor, temperature becomes the dominant forcing factor (Curiel Yuste et al., 2007).

In this paper, the Riparian Soil Model (RSM, Brovelli et al., 2012) was tested through application to a recently restored riparian ecosystem. The model was further applied to study the relationships between intertwined environmental parameters governing nutrient cycles in riparian systems at a daily time-scale. The field site, sampling and monitoring procedures are described in Sec. 2. Modelling results, validated with experimental measured data, are presented in Sec. 3. Finally, in Sec. 4 the model is used to study the effect of environmental controls in riparian soils.

\section{Materials and methods}

\subsection{Field site}

The research site was a revitalized section of the Thur River, near Niederneunforn, northeast Switzerland, with a mean altitude of about $375 \mathrm{~m}$ (Fig. 1). The Thur River is the largest Swiss river without a natural or artificial reservoir along its course, with a total length of $127 \mathrm{~km}$ and a catchment area of $1750 \mathrm{~km}^{2}$. The river flows through an area of intensive agriculture and substantial urbanisation, and is heavily impacted by anthropogenic activities. At the experimental site, the riverbed crosses glacio-fluvial sandy gravel sediments of about 6-m thickness, which overlay impervious lacustrine clays (Vogt et al., 2010).

During restoration in 2002, the width of a section of the main river channel was doubled to about $100 \mathrm{~m}$ for $2.5 \mathrm{~km}$ by removal of overbank material and levees. Groundwater flows from 
the river towards the side channel, located at a distance of about $180 \mathrm{~m}$ in the alluvial forest.

Over a distance of 40 to $60 \mathrm{~m}$ there is a lateral successional gradient from the river to the forest including bare gravel, gravel overlaid by fresh fluvial sediments, i.e., deposited after the restoration, colonized by mainly canary reed grass (Phalaris arundinacea), old overbank sediments planted with young willows (Salix viminalis) during the restoration, and finally the mature riparian hardwood forest developed on older overbank sediments with ash (Fraximus excelsior L.) and maple (Ace sp.) as the dominant trees. A footpath separates the willow bush zone and the forest.

The selected monitoring-sampling point F2 is located in the forest about $10 \mathrm{~m}$ from the footpath (Fig. 1). In spring, the ground vegetation is dominated by wild garlic (Allium ursinum L.), later in summer, Aegopodium podagraria L., Rubus fructicosus and nettle (Urtica dioica L.) become dominant. The alluvial soil is a carbonate-containing loam to siltyloam displaying little variation with depth (Table 1).

\subsection{Soil sampling, processing and analysis}

Samples for basic soil characterization were collected in May 2008. Within each of the three plots in the forest (with a diameter of $8 \mathrm{~m}$ ), two cores were taken using a hand auger to a depth of $1 \mathrm{~m}$ and divided into $20 \mathrm{~cm}$ segments. For each plot, corresponding segments of the two cores were pooled for sample preparation and analysis. Samples were dried at $40^{\circ} \mathrm{C}$ and sieved to $2 \mathrm{~mm}$. The clay $(<2 \mu \mathrm{m})$ and silt $(2-63 \mu \mathrm{m})$ fractions were determined after removal of organic matter by treatment with hydrogen peroxide using the pipette method of Gee and Bauder (1986). Organic C contents of ground samples were determined with an elemental analyser (NC2500, CE Instruments, Italy) after removal of carbonates by acid treatment, and total $\mathrm{N}$ contents were determined on untreated samples using the same analyser (Walthert et al., 2010). 
119 Between autumn 2008 and spring 2010, the water content at depths of 10 and $50 \mathrm{~cm}$ was

120 measured at 30-min intervals at three replicate locations (parallel to river, $5.5 \mathrm{~m}$ distance

121 between locations, 2 locations within sampling plot, 1 location outside) using EC-5 and EC-

122 TM sensors (Decagon Devices Inc.). Raw signals were converted to volumetric water content

123 using customized calibrations. For one of the three replicates for each depth, temperature was

124 measured using EC-TM sensors.

125 Between autumn 2008 and autumn 2009, the soil efflux of $\mathrm{CO}_{2}$ and $\mathrm{N}_{2} \mathrm{O}$ was measured using 126 a pre-installed PVC ring (30-cm diameter and 30-cm long inserted 20-cm deep in soil).

127 Immediately before sampling, vegetation within the ring was clipped and the chamber closed

128 with an airtight lid. Headspace air samples were collected after 5, 25 and 45 min, injected into

129 pre-evacuated glass vials ('exetainers'), and analysed for $\mathrm{CO}_{2}$ and $\mathrm{N}_{2} \mathrm{O}$ concentrations using a

130 gas chromatograph with an electron-capture detector (Agilent 6890, Santa Clara, USA). The

131 soil-atmosphere $\mathrm{N}_{2} \mathrm{O}$ exchange rate was calculated by linear regression of concentration

132 against time. From April to October 2009 the sampling interval was $14 \mathrm{~d}$ on average, but

133 higher and lower sampling frequencies were adopted after major flood events in June and July

1342009 and dry periods in August and September, respectively.

135 The soil solution was regularly sampled between spring 2009 and spring 2010, until October

1362009 at the same dates as the gas efflux, then in monthly intervals. Soil solution was collected

137 using tension lysimeters based on ceramic suction cups (Soil Moisture Inc.) that were pre-

138 installed at the same depths as and in close vicinity to the water content sensors. At each

139 sampling, a constant vacuum was applied at $-60 \mathrm{kPa}$ for up to $2 \mathrm{~d}$. The soil solution samples,

140 as well as deposition and river water samples taken at the same time, were immediately

141 filtered $(0.45 \mu \mathrm{m})$ and stored at $2{ }^{\circ} \mathrm{C}$. These samples were analysed for $\mathrm{NH}_{4}$ (flow injection

142 analysis based on alkalinisation and diffusion of $\mathrm{NH}_{3}$ into an acid carrier followed by 
143 colorimetric detection of an indicator dye), $\mathrm{NO}_{3}$ (direct colorimetry, Navone 1964) and non-

144 purgeable organic C (elemental analyser, Skalar Formacs HT and TN).

145 Samaritani et al. (2011) presented a study relating variability of $\mathrm{C}$ pools and fluxes $\left(\mathrm{CO}_{2}\right)$ to

146 soil properties, environmental conditions and flood disturbance in a revitalized section of the

147 Thur River. They found that, overall, environmental conditions driven by seasonality and

148 flooding affected soil $\mathrm{C}$ dynamics more than soil properties did. In comparison with the

149 frequently flooded gravel bars, the riparian forest, data of which are used in the present study,

150 was rather stable with comparatively small spatial heterogeneity due to only rare flooding

151 events. It was also characterized by relatively high organic $\mathrm{C}$ contents and water retention

152 capacity both of which could be related to the relatively fine soil texture.

$153 \quad 2.3$ Soil C and $N$ modelling

154 The data collected during 2008-2010 were used to validate the model of Brovelli et al. (2012).

155 Ideally, model parameters should be independently measured through ad hoc laboratory

156 experiments. Although attractive, this approach has shown limited applicability because in

157 laboratory experiments conditions are idealized, and the computed parameters normally over-

158 estimate the field values. On the other hand, field experiments cannot be used to infer directly

159 the model parameters, as they are influenced by changing environmental conditions (moisture

160 content, temperature, nutrient availability, etc). The calibration was therefore performed with

161 a trial-and-error approach, during which model parameters controlling the different processes

162 were tuned to match the measurements, in particular OM degradation and mobilization rates

$163\left(k_{l}, k_{h}\right.$ and $\left.k_{d}\right)$, respiration coefficients ( $r_{h}$ and $r_{r}$, respectively), plant uptake factors and

164 nitrification/denitrification rates ( $k_{n}$ and $k_{\text {denit }}$, respectively).

165 Four external processes were assumed to drive the dynamics of SOM decomposition and

166 nutrient turnover: precipitation, temperature, vegetation uptake (evapotranspiration, EVT, and

$167 \mathrm{~N}$ uptake) and organic matter release (litter inputs and root exudates): 
169 Daily rainfall measurements at the Thur site recorded in parallel to soil data monitoring were

170 used as input in the model (Fig. 2a).

\section{Temperature}

172 The soil surface temperature (at $z=0$ ) and the thermal diffusivity of the soil are required as

173 input in the RSM model to simulate the temperature profile. Air temperature measured at a

174 meteorological station nearby the sampling point was applied as a boundary condition at the

175 soil surface. Soil parameters (porosity and soil field capacity) were taken from the root zone

176 and assumed constant along the soil profile to compute soil thermal capacity. Soil thermal

177 conductivity was calibrated using the measured values at two depths $\left(z_{1}=40 \mathrm{~cm}\right.$ and $z_{2}=100$

$178 \mathrm{~cm})($ Fig. 2b).

179 Vegetation uptake

180 Vegetation influences directly the soil moisture through transpiration and the mineral $\mathrm{N}$

181 stocks via plant root uptake. Plant transpiration was modelled in combination with

182 evaporation as described by Brovelli et al. (2012), with parameters suitable for a forest soil

183 (Batlle-Aguilar et al., 2011). The parameters needed in the model are listed in Table 2 and

184 include the level of incipient stress $\left(s^{*}\right)$, hygroscopic and wilting points $\left(s_{h}\right.$ and $s_{w}$,

185 respectively), soil field capacity $\left(s_{f c}\right)$ and the effect of temperature on plant transpiration $\left(f T_{r}\right)$.

186 Note that in the EVT modelling approach used by the RSM simulator, canopy interception is

187 directly removed from precipitation, rather than being considered in the computations of EVT

188 (see Rodriguez-Iturbe et al., 1999 for details). Plant physiological processes, transpiration and

189 nutrient uptake in particular, vary temporally. The annual cycle of vegetation was introduced

190 using the plant activity coefficient, as defined in Eq. (21) in Brovelli et al. (2012). The activity

191 coefficient applied at the Thur site is shown in Fig. 2c (red dashed line). Parameters were

192 taken from the literature, considering a similar vegetation and climate (Gu et al., 2008). Plant 
activity closely follows the annual temperature cycle, and therefore the activity coefficient is a

194 maximum in late spring/early summer and starts to decline during July. From October to the end of the winter season plants are quiescent. Root uptake follows the same temporal dynamics of plant activity, with the maximum uptake occurring in late spring to sustain the

197 vigorous plant growth.

\section{Litter input and root exudates}

199 Vegetation contributes to SOM through litter addition and production of root exudates. The timing, amount and $\mathrm{C}: \mathrm{N}$ ratio of the $\mathrm{OM}$ released are all important factors for nutrient dynamics. The C:N ratio of the added litter $\left(C N_{a d d}\right)$ is controlled by the vegetation type and is smaller for fallen leaves than for hardwood. An average value of 15 was used, which is suitable for Swiss forests (Heim and Frey, 2004; Tietema et al., 1998). Root exudates were assumed to have a higher $\mathrm{N}$ content, as vegetation produces these organic molecules to foster microbial communities in the root zone, and a value of 13 was used (Kuzyakov, 2002; Rovira, 1969). OM release follows an annual cycle, although litter production and root exudates have

207 different timing. Root exudates are produced when the plant is active and therefore their 208 dynamics are similar to that of transpiration and N uptake. Litter release has two components:

209 One is constant through the year (for example, fallen branches and leaves after a storm or a 210 fire, etc.), while the other has a peak in autumn due to falling leaves as plants enter the 211 quiescent state. The amount of OM litter released from the vegetation is presented in Fig. 2c.

212 Measurements of litter inputs at the Thur site were not available, and therefore literature 213 values for similar vegetation, latitude and climatic conditions were adopted (Bell, 1978; Finzi 214 et al., 2001). 


\section{Results}

\subsection{Environmental controls and moisture dynamics}

218 The computed EVT (evaporation from the soil and plant transpiration) is shown in Fig. 2a.

219 EVT is largest in early summer, when both plant transpiration and soil evaporation are near 220 their maximum value (as temperature is also near its peak). EVT reaches its lowest value in 221 winter, particularly January to February. Some of the parameters (particularly the maximum 222 EVT rate and the minimum evaporation rate) were adjusted slightly to match the soil moisture 223 data. However, it was found that, below a certain value, the minimum evaporation rate (0.5 $224 \mathrm{~mm} \mathrm{~m}^{-2} \mathrm{~d}^{-1}$ ) plays virtually no role, and therefore the estimated value might not be reliable. 225 Although EVT data were not available to validate the simulation results, the model predicts 226 that the total soil transpiration and evaporation is about $350 \mathrm{~mm} \mathrm{y}^{-1}$. The total 227 evapotranspiration (i.e., including vegetation interception and evaporation) can be computed 228 from the difference between infiltration and leakage, and amounts to about $710 \mathrm{~mm} \mathrm{y}^{-1}$, which 229 compares well with other estimates and measurements for wet areas/shrubs/mixed forests at a 230 similar latitude and altitude in the Thur catchment (Gurtz et al., 1999). Fig. 2b reports daily 231 averages of soil temperature measurements (solid lines) and corresponding model predictions 232 (dashed lines), at two different depths. These measurements were used only to calibrate the 233 parameters for the temperature model. The comparison is satisfactory, and the thermal 234 diffusivity (Table 3) falls within literature ranges for this soil type (Wu and Nofziger, 1999). 235 The main noticeable difference for the measurements at $z_{1}(40-\mathrm{cm}$ depth) is the presence of 236 high frequency fluctuations (with a period of a few days and amplitude of about $3-5^{\circ} \mathrm{C}$ ) 237 starting around the beginning of April 2009. These fluctuations were attributed to problems 238 with the temperature sensors that were perhaps exposed directly to air due to the opening of 239 cracks or earthworm channels during the summer period. 
240 Field measurements and modelling results of water saturation in the topsoil (first $10 \mathrm{~cm}$

241 depth) and root zone (between 10 and $60 \mathrm{~cm}$ depth) are presented in Fig. 3, while the

242 calibrated soil properties are listed in Table 2. Despite the simplicity of the moisture balance

243 model, the simulations mimic well the temporal dynamics of water saturation in both soil

244 layers. The comparison is, however, slightly better for the topsoil because the water dynamics

245 in this layer are mainly controlled by precipitation/EVT and are less sensitive to soil

246 properties. Due to heavy precipitation in the upper part of the catchment, the Thur River water

247 level rose in mid-July 2009, but the nearby alluvial plain was not flooded. The groundwater

248 level at a piezometer a few metres from the soil sampling point (R017) followed the river

249 dynamics. The water table was only $0.4 \mathrm{~m}$ below the ground surface, while in normal

250 conditions it is about 2-m deep (data not shown). This event was well reproduced by the

251 model, resulting in nearly saturated conditions in the root zone and high saturation in the top

252 soil (Fig. 3).The main discrepancy between measurements and simulations occurs in the

253 initial period between November and December 2008. In these two months, the model

254 systematically underpredicts the measured moisture content in both layers. The simulated

255 topsoil data show temporal dynamics that are similar to the measurements, although shifted

256 by about 0.2 towards drier conditions. A similar difference (but less pronounced) is also

257 visible one year later, in November 2009. Groundwater elevation data at R017 showed that

258 the water table rose in the same period, remaining at about $1 \mathrm{~m}$ below the soil surface. In the

259 same period, the soil surface was partially ponded for some days.

$2603.2 \quad$ Immobile OM pools and soil respiration

261 Soil respiration data and model predictions are reported in Fig. 4a, together with the temporal

262 evolution of the $\mathrm{C}$ stored in the immobile OM pools (Fig. 4b-d for litter, humus and biomass,

263 respectively). The calibrated biogeochemical parameters are listed in Table 4. Only the

264 parameters for the topsoil and root zone are reported, for which experimental data were 
available. The default parameters used for the rest of the profile (compartments 3 and 4,

266 parent material and aquifer, respectively) are identical to those listed by Brovelli et al. (2012, 267 Table 2).

268 Table 5 summarizes experimental and modelled total organic $\mathrm{C}\left(C_{\text {org }}\right)$ and $\mathrm{C}: \mathrm{N}$ ratios in the 269 topsoil and root zone at the monitoring-sampling point. The model reproduces satisfactorily 270 the field observations. The simulated $\mathrm{C}: \mathrm{N}$ ratios are similar to the measured values, indicating 271 that the value used for the litter input is appropriate. The predicted organic $\mathrm{C}\left(C_{\text {org }}\right)$ in the soil 272 was computed as the average ( \pm 1 standard deviation) of the simulation results for a period of $2735 \mathrm{y}$ (after the model was run to reach pseudo-steady state, in order to remove the influence of 274 the initial condition). Measurements are instead the average ( \pm 1 standard deviation) of 275 different soil samples all collected at the same time. The predicted values fall well within the 276 observed ranges. The comparison further indicates that the field heterogeneity (given by the 277 standard deviation of $C_{\text {org }}$ ) is larger than the expected range of fluctuation over 1 year. This 278 might result from local micro-topography, which leads to areas where OM accumulates and 279 others where it is depleted.

280 Soil respiration (measured as soil $\mathrm{CO}_{2}$ efflux) was assumed to be the cumulative microbial 281 respiration (decomposition of organic matter) in the two uppermost compartments. The model 282 assumes that all the $\mathrm{CO}_{2}$ produced within the soil profile immediately reaches the atmosphere, 283 that is, the diffusion time is negligible compared to the model's 1-d time step. The importance 284 of root (or autotrophic) respiration has been highlighted recently, and it has been suggested 285 that it could contribute up to half the total soil $\mathrm{CO}_{2}$ efflux (Fenn et al., 2010; Subke et al., 286 2011). The RSM model does not consider it explicitly (i.e., as a separate $\mathrm{CO}_{2}$ source), rather 287 the total respiration (i.e., of roots and biomass) is computed. This is a convenient 288 approximation because (i) the knowledge of the different respiration processes occurring in 289 the rhyzosphere is still incomplete, and (ii) ad hoc experiments to evaluate the relative 
contribution of root respiration to $\mathrm{CO}_{2}$ efflux - a necessary input for a model - are seldom, if

291 ever, conducted. The model could be extended once more insights into these processes

292 become available. Soil respiration was calibrated adjusting the decomposition rates and 293 respiration efficiencies. Microbial decomposition rates were set to $10^{-6} \mathrm{~m}^{3} \mathrm{~d}^{-1} \mathrm{gC}^{-1}$ for litter

$294\left(k_{l}\right)$ and humus $\left(k_{h}\right)$, which are consistent with the estimates of Paul and Clark (1996) and 295 Hefting et al. (2005). Following Jenkinson and Coleman (2008), the C litter input rate due to 296 biomass lysis (release of compounds from cells of dead microorganisms), $k_{d}$, was fixed at 7.5 $297 \times 10^{-3} \mathrm{~d}^{-1}$. Isohumic and respiration coefficients, $r_{h}$ and $r_{r}$ respectively, were calibrated as 0.27 298 and 0.60, respectively, in agreement with values reported by Brady and Weil (2004) and 299 Nesme et al. (2005). The model reproduces satisfactorily the seasonal pattern observed in the 300 experimental data $\left(\mathrm{R}^{2} \approx 0.75\right)$, with respiration increasing from a minimum in winter to a 301 maximum in early summer (Fig. 4a). A detailed analysis of the environmental factors 302 influencing this increase is presented below. Here, we mention only that during calibration it was observed that the most influential parameter was the temperature sensitivity coefficient.

304 Clearly, the dynamics of respiration is linked to that of the immobile $\mathrm{C}$ pools, and a visual 305 comparison indicates that the strongest (negative) correlation is between litter and biomass pools in the topsoil. The C litter pool (Fig. 4b, dashed line) shows the largest seasonal fluctuations, with the stored $\mathrm{C}$ reaching a maximum and a minimum at the end of the winter 308 and summer seasons, respectively. The position of the peaks is offset in time compared to 309 respiration. The accumulation of litter in the topsoil during autumn and winter is due to the combination of two processes, i.e., fallen leaves and accumulation of dead pedofauna. The 311 two processes have different timing, the former has a maximum in October (Fig. 2c), while 312 biomass accumulation is largest in January, corresponding to the lowest temperatures. In this 313 period, biomass activity is a minimum, and the lysis rate exceeds the growth rate, with a net 314 reduction of the biomass pool (Fig. 4d). On the contrary, during summer, biomass activity is 
high, the growth rate exceeds the lysis rate and the living biomass pool increases. In parallel,

316 litter is consumed through soil respiration and converted to humus (Fig. 4c) and $\mathrm{CO}_{2}$. For this

317 reason, the humus pool shows a maximum in the same period, although the amplitude of the

318 fluctuations is much smaller than for the other immobile $\mathrm{C}$ pools.

\subsection{Dissolved organic matter (DOC and DON)}

DOM sources are the dissolution of organic matter and plant root exudates. Litter and humus mobilisation rates, $k_{C l}$ and $k_{C h}$, were calibrated, respectively, to $10^{-6} \mathrm{~d}^{-1}$ and $5 \times 10^{-7} \mathrm{~d}^{-1}$, which are consistent with the values reported by Bengtson and Bengtsson (2007). Root exudation rates were calibrated to 0.1 and $0.03 \mathrm{~g} \mathrm{~m}^{-3} \mathrm{~d}^{-1}$ for the topsoil and root zone, respectively. It is difficult to compare the exudates production rates with literature values because most available estimates were derived from measurements in laboratory-controlled conditions (for example, hydroponic setups). Moreover, root exudates are strongly variable in time - their production rate is affected by environmental factors, such as humidity, temperature, nutrient availability and vegetation type (Kuzyakov, 2002; Rovira, 1969). Despite this limitation, the values used in the model appear realistic when compared with literature values for forests. For example, although for a different vegetation (loblolly pine forest), Phillips et al. (2009), assuming a constant production rate, estimated from in situ measurement during the growing season a total of $9.4 \mathrm{~g} \mathrm{~m}^{-2} \mathrm{y}^{-1}$, which compares well with the value predicted using the RSM $\left(7.3 \mathrm{~g} \mathrm{~m}^{-2} \mathrm{y}^{-1}\right)$. The rates used in the model decrease with depth because the rate of exudate production depends on the root density and activity (Rovira, 1969): Since generally root density decreases almost exponentially with depth, the exudate production rate is much higher in the topsoil than in the root zone.

The modelled temporal evolution of the dissolved pools is compared with measurements in

Fig. 5. For DOC, the topsoil measurements are reproduced correctly by the model, as indicated by the high $\mathrm{R}^{2}$. Low DOC concentrations, in comparison with the immobile OM, 
occur because soluble $\mathrm{C}$ (i) is consumed rapidly by microbial pedofauna (in particular, low-

341 molecular weight root exudates) and (ii) drains away with water flow. For the root zone, the

342 model shows a trend similar to the experimental data, with a peak followed by a slow

343 decrease. The peak is achieved about a month early, with a too-fast DOC accumulation in

344 spring and early summer. A better fit (in terms of correlation coefficient) could be achieved

345 by reducing the rate of root exudate production, but in this case simulations would miss the

346 peak observed in late August. A possible explanation for the discrepancies is the partitioning

347 or adsorption of DOC on the immobile OM or mineral solid phase (for example, clays) and

348 colloids (Pérez et al., 2011; Schijf and Zoll, 2011), a process that is not included in the model.

349 Simulated DON concentrations are also reported (Fig. 5b), but experimental data were not

350 available. The same patterns observed for DOC were also found for DON, as the model

351 assumes that organic matter dissolution influences $\mathrm{C}$ and $\mathrm{N}$ in a similar way, the only

352 difference being the relative amounts, which are controlled by the $\mathrm{C}: \mathrm{N}$ ratio.

3.4 Inorganic $N$

354 Mineral N pools are controlled by the balance between mineralization and immobilization

355 (Porporato et al., 2003). In environments where $\mathrm{N}$ is abundant, such as the Thur site, organic

$356 \mathrm{~N}$ is available in excess and mineralization dominates over immobilization. Mineral $\mathrm{N}$ (in

357 particular, nitrates) is removed by plants, leaches to the aquifer and a fraction is lost to the

358 atmosphere through denitrification. This latter is a microbial anaerobic process that involves

359 the use of nitrate as electron acceptor and its transformation to gaseous inorganic N. The

360 reaction is complete when nitrates are converted to $\mathrm{N}_{2}$, a situation that seldom occurs. Instead

361 of $\mathrm{N}_{2}, \mathrm{~N}_{2} \mathrm{O}$ is produced and released to the atmosphere. Although $\mathrm{N}_{2} \mathrm{O}$ is produced also

362 during nitrification, its main source is denitrification, and little is known about the

363 environmental parameters that control its production (Del Grosso et al., 2000), although it is

364 of great interest environmentally as it is a potent greenhouse gas (Cuhel et al., 2010). The 
denitrification rate depends on soil chemical and physical conditions such as oxygen content, 366 temperature and $\mathrm{pH}$ (Heinen, 2006). Denitrification removes nitrate from the pore-water, and therefore nitrate leakage to the aquifer is reduced. This is a key ecological function of riparian buffers, which are able to reduce $\mathrm{N}$ inputs coming, for example, from fertilizers. To describe this process, RSM uses a first-order denitrification rate $\left(k_{\text {denit }}\right)$ scaled by an activity coefficient

370 that accounts for the water saturation level (and ultimately for oxygen availability). The 371 denitrification rate resulting from calibration is $7.5 \times 10^{-3} \mathrm{~d}^{-1}$, which falls into the range of 372 Heinen (2006), while the nitrification rate $\left(k_{n i t}\right)$ for the topsoil and root zone were calibrated 373 nitrate inputs.

The total plant nitrogen uptake is related to a threshold rate for both ammonium and nitrate

384 species $\left(\mathrm{DEM}^{+}\right.$and $\mathrm{DEM}^{-}$, respectively), which defines the actual uptake rate. $\mathrm{DEM}^{+}$and $385 \mathrm{DEM}^{-}$were calibrated as 0.06 (topsoil and root zone) and 0.01 and $0.015 \mathrm{~g} \mathrm{~N} \mathrm{~m}^{-3} \mathrm{~d}^{-1}$ (topsoil 386 and root zone, respectively), an order of magnitude smaller than those reported by D'Odorico 387 et al. (2003) for savannah soils (Table 2). In arid environments, such as savannah, plants are 388 well adapted to uptake quickly available soil $\mathrm{N}$, as this is only available as pulses after short 389 precipitation events (D'Odorico et al., 2003). In riparian soils like the Thur site, $\mathrm{N}$ is available 
the entire year, in particular during the growing season, thus plant uptake rates are lower but

391 continuous during the year. Despite the higher rate, in the savannah the total amount of

392 mineral $\mathrm{N}$ removed by plants during a year is lower than in deciduous forests with temperate

393 climate.

$394 \mathrm{NO}_{3}{ }^{-}$concentrations and $\mathrm{N}_{2} \mathrm{O}$ efflux with time are presented in Fig. 6. The $\mathrm{NO}_{3}{ }^{-}$dynamics are 395 captured well by the model in both topsoil and root zone. The model is also able to reproduce 396 the $\mathrm{N}_{2} \mathrm{O}$ pulses, although timing and magnitude do not match. These pulses were due to two 397 major flooding events, which caused wet conditions that favoured denitrification and $\mathrm{N}_{2} \mathrm{O}$ 398 emissions.

399 The mismatch in $\mathrm{N}_{2} \mathrm{O}$ fluxes was not unexpected, because $\mathrm{N}_{2} \mathrm{O}$ production is extremely 400 variable as it depends on the local physical environment, physiological characteristics of the 401 microbial community, C availability, redox potential and soil acidity (Firestone et al., 1980). 402 Moreover, it should be considered that the model predicts the total inorganic $\mathrm{N}$ efflux (i.e., $\mathrm{N}_{2}$ 403 gas and $\mathrm{N}_{2} \mathrm{O}$ ), and the relative composition of the $\mathrm{N}$ flux varies with time. For this reason, it is 404 expected that model results will over-predict the measured $\mathrm{N}_{2} \mathrm{O}$ flux. Regarding the slightly 405 different timing of the pulse, similar to soil respiration the model computes $\mathrm{N}$ efflux as sum of 406 denitrification products in the topsoil and root zone, neglecting the diffusion/advection time 407 through the soil profile. Moreover, the model assumes that the onset of wet conditions triggers 408 immediately the denitrification reaction. This is not entirely correct, as nitrate reduction 409 commences only when dissolved oxygen is consumed, a process that can introduce a lag time 410 for denitrification (perhaps 1-2 d).

\section{Sensitivity to environmental forcing}

413 Numerous studies have highlighted that, at most temperate-climate sites, nutrient turnover is

414 sensitive to both soil moisture and temperature (Curiel Yuste et al., 2007; Hagedorn et al., 
2010; Pietikåinen et al., 2005). In arid and semi-arid environments with high constant

416 temperatures, such as in the savannah (D’Odorico et al., 2003; Porporato et al., 2003;

417 Rodriguez-Iturbe and Porporato, 2004), soil moisture is the main driver of OM cycling. The

418 sensitivity of the different processes to each of these factors is still debated, and probably

419 depends on the specific characteristics (geology, climate, etc.) of the site considered.

420 Understanding the effect and relative sensitivity to changes in environmental variables is

421 important in order to forecast future evolution of ecosystems when the environmental forcing

422 factors change, for example restoration or climate change.

423 The sensitivity of $\mathrm{C}$ and $\mathrm{N}$ turnover to different environmental parameters in the forest near

424 the restored Thur transect is presented in Figs. 7-9. Fig. 7a-b presents the influence of water

425 saturation and temperature on soil respiration $\left(\mathrm{CO}_{2}\right.$ efflux $)$, which is a good indicator of the

426 soil microbial activity. Soil temperature and respiration show a positive correlation whereas

427 the influence of water saturation is limited. This agrees with the observations of Bengtson and

428 Bengtsson (2007) and Hui and Luo (2004) in forests with a similar climate, who reported that

429 soil temperature is perhaps the most influential factor regulating $\mathrm{CO}_{2}$ efflux. Davidson et al.

430 (1998) studied the interplay between soil moisture and temperature in a hardwood forest in a

431 temperate climate (i.e., in conditions comparable to those of the field site studied here), and

432 observed that moisture becomes a critical parameter for nutrient turnover in dry periods with

433 high temperature. At the Thur site, water availability is fairly constant across the year, and

434 seldom falls below field capacity (Fig. 2).

435 To analyse the effect of temperature on the soil ecosystem, Q10 was computed using

436 experimental data and model results for the period 2008-2009. A significantly different value

437 was found for each period of the year: 2.9 for the period January-April, 2.1 for May-July and

4381.3 for August-October. These values reproduce the seasonal variability observed by Xu and

439 Qi (2001), with the annual minimum occurring in mid-late summer, and the maximum 
occurring in winter. The variability is associated with annual changes in soil functioning: In

441 January, plants and microbial pedofauna are quiescent, and the increase in temperature

442 occurring in March-April boosts their activity. In the following period (May-June), the

443 turnover rate further accelerates, and reaches a plateau around mid-June (the relationship

444 between microbial rates and temperature changes is highly non-linear, see Brovelli et al.

445 (2012). Afterwards, the temperature decreases again, but the rates remain relatively high

446 because, at the end of summer, living microbial biomass and litter are both abundant. The

447 seasonal Q10 variability suggests that the effects of environmental factors on nutrient

448 turnover and $\mathrm{CO}_{2}$ fluxes must be considered on the seasonal scale, and that average annual

449 values may not be indicative of the sensitivity of soil respiration to temperature changes. This

450 is consistent with the findings of others (Gu et al., 2004, 2008 and references therein), who

451 observed that the relationship between $\mathrm{CO}_{2}$ efflux and soil temperature must always be

452 corrected for the effect of other environmental parameters, in particular soil moisture.

453 Fig. $7 \mathrm{c}$ presents the relationship between $\mathrm{NO}_{3}$ concentration and $\mathrm{C}: \mathrm{N}$ ratio. Although the $\mathrm{C}: \mathrm{N}$

454 ratio variations are small, a negative correlation is apparent. When the organic matter is $\mathrm{N}$ -

455 poor (high $\mathrm{C}: \mathrm{N}$ ratio), low $\mathrm{NO}_{3}$ concentrations are observed, and vice-versa. Goodale and

456 Aber (2001) and Ollinger et al. (2002) observed that high C:N ratios produced a strong N

457 demand by heterotrophic soil microbes, leaving less $\mathrm{N}$ available for nitrification and

458 subsequent nitrate leaching. This mechanism is compatible with measurements and

459 predictions at the Thur site. $\mathrm{N}_{2} \mathrm{O}$ emissions are controlled primarily by the moisture content

460 (Brovelli et al., 2012), with pulses occurring in wet conditions (model results not shown). The

461 effect of temperature on denitrification is instead almost negligible, as illustrated in Fig. 7d.

462 Similar to soil respiration, soil temperature and water saturation have a completely different

463 influence on DOC. According to modelling results, soil temperature and DOC show a positive

464 relationship, with high concentrations of organic $\mathrm{C}$ at high temperatures (Fig. 8a shows the 
results for the root zone). From the comparison, the discrepancies between model predictions

466 and experimental data are clearly visible. In particular, the model consistently over-estimates

467 the measurements at high temperature $\left(>16^{\circ} \mathrm{C}\right)$, whereas the measurements at low

468 temperature are well reproduced. This indicates that the seasonal contribution of plant root

469 exudates is over-estimated by the model or that the biomass uptake when soil temperature is

470 optimal is too small. The relationship between soil temperature and DOC is however weaker

471 than that with soil respiration, consistent with the results of Hagedorn et al. (2010). In

472 contrast, water saturation has negligible influence on DOC, as highlighted in Fig. 8b.

473 Experimental results confirmed the model results, therefore suggesting that the reason for the 474 mismatch is not related to moisture dynamics.

475 The existence of a correlation between soil respiration and DOC concentration has been 476 debated and no clear answer has been reached. Neff and Asner (2001) and Van Hees (2005) 477 hypothesized that DOC was the main source of soil respiration. On the contrary, Bengtson 478 and Bengtsson (2007) and Gödde et al. (1996) found that the $\mathrm{CO}_{2}$ evolution and DOC 479 concentration were not significantly correlated to each other as they are controlled by 480 different processes and chemistry. The positive relationship between soil temperature, soil 481 respiration and DOC was highlighted above. Simulation results show that the two variables 482 are positively correlated (Fig. 9). The experimental data do not confirm the existence of a 483 correlation, although they fall well within the range predicted by the model. On the other 484 hand, analysis of the $\mathrm{CO}_{2}$ sources based on model predictions indicates that, at the end of the 485 growing season, consumption of root exudates can represent a significant $\mathrm{CO}_{2}$ source, thus 486 partially confirming the findings of Neff and Asner (2001) and Van Hees (2005). However, 487 given the limited ability of the model to reproduce DOC in the root zone this conclusion 488 should be further tested using additional experimental data. 


\section{Summary and conclusions}

491

492

493

494

495

496

497

498

499

500

501

502

503

504

505

506

507

508

509

510

511

512

513

The Riparian Soil Model (RSM, Brovelli et al., 2012) was validated through application to a recently restored riparian ecosystem in North-East Switzerland. The model was further used to study the relationships between intertwined environmental parameters governing nutrient cycles in riparian systems.

Modelling results reflect parameter values, and accurate estimation of these values reduces model uncertainty. Experimental data often exhibit spatial and temporal variability due to heterogeneity, instrumental accuracy, amongst other factors occurring in the field.

Nevertheless, model parameters were satisfactorily constrained by closely fitting the experimental field data. The model was able to reproduce well the experimental data for the immobile SOM pools, and for the inorganic N fluxes. In particular, the trends observed in the field were in most cases reproduced correctly, thus providing some confidence in the reliability of the model. Simulations less satisfactorily reproduced DOC data, in particular for the root zone. Numerical experiments were conducted to ascertain which process could be responsible for the mismatch, but no clear answer was found.

Soil temperature, with large daily and seasonal oscillations, was identified as the main environmental factor controlling the microbial processes. The effect of moisture content was limited, mainly because at the Thur River site moisture is never a limiting factor for the plants and soil biota.

At the Thur River site, $\mathrm{N}$ is abundant and does not limit $\mathrm{OM}$ turnover. During the warm period (April-September), organic $\mathrm{N}$ is available in excess and is converted to nitrate. Nitrate release is however particularly marked in July and August, since during spring vigorous vegetation growth takes up mineral $\mathrm{N}$ and reduces its concentration in the pore water. $\mathrm{N}$ availability is mainly controlled by the $\mathrm{C}: \mathrm{N}$ ratio of the $\mathrm{OM}$ released by vegetation (plant 
514 litter and root exudates), which implies that the $\mathrm{N}$ cycle is regulated, at least in part, by

515 vegetation composition.

516 The ecosystem sensitivity to soil temperature changes was quantified through the Q10 index

517 and compared with previous results obtained in similar conditions. Results were in good

518 agreement with literature values and, more importantly, the seasonal Q10 variability reported

519 elsewhere was reproduced. This further confirms that analysis and predictions of soil $\mathrm{CO}_{2}$

520 releases are only meaningful if conducted at the seasonal scale, including the effects of other

521 relevant environmental forcing factors and the evolution and state of the soil biota.

\section{Acknowledgements}

This research is part of the RECORD project of the Competence Centre Environment

526 and Sustainability (CCES, http://www.cces.ethz.ch/projects/nature/Record). Funding was

527 provided by the Swiss National Science Foundation (grant 200021-113296). We thank

528 Bertrand Fournier (University of Neuchâtel, Switzerland) for information on dominant plants,

529 and Paolo Perona (EPFL, Switzerland) and Nicola Pasquale (ETHZ, Switzerland) for

530 meteorological data. 
Batlle-Aguilar J, Brovelli A, Porporato A, Barry DA. Modelling soil carbon and nitrogen cycles during land use change. A review. Agron. Sustain. Dev. 2011; 31: 251-274.

Brovelli A, Batlle-Aguilar J., Barry DA. Analysis of carbon and nitrogen dynamics in riparian soils. Model development. Submitted to Sci. Total Environ. 2012.

Beier C, Emmett BA, Peñuelas J, Schmidt IK, Tietema A, Estiarte M, et al. Carbon and nitrogen cycles in European ecosystems respond differently to global warming. Sci. Total Environ. 2008; 407: 692-697.

Bell C, McIntyre N, Cox S, Tissue D, Zak J. Soil microbial responses to temporal variations of moisture and temperature in a Chihuahuan desert grassland. Microb. Ecol. 2008; 56: 153-167.

Bell DT. Dynamics of litter fall, decomposition, and incorporation in the streamside forest ecosystem. Oikos 1978; 30: 76-82.

Bengtson P, Bengtsson G. Rapid turnover of DOC in temperate forests accounts for increased $\mathrm{CO}_{2}$ production at elevated temperatures. Ecol. Lett. 2007; 10: 783-790.

Brady NC, Weil RR. Elements of the nature and properties of soils. New Jersey (USA): Pearson Prentice Hall, 2004.

Correll DL. Buffer zones and water quality protection: general principles. In: Haycock NE, Burt TP, Goulding KWT, Pinay G, editors. International Conference on Buffer Zones, 1997, pp. 7-20.

Cuhel J, Simek M, Laughlin RJ, Bru D, Cheneby D, Watson CJ, et al. Insights into the effect of soil $\mathrm{pH}$ on $\mathrm{N}_{2} \mathrm{O}$ and $\mathrm{N}_{2}$ emissions and denitrifier community size and activity. Appl. Environ. Microbiol. 2010; 76: 1870-1878.

Curiel Yuste J, Baldocchi DD, Gershenson A, Goldstein A, Misson L, Wong S. Microbial soil respiration and its dependency on carbon inputs, soil temperature and moisture. Global Change Biol. 2007; 13: 2018-2035.

D’Odorico P, Laio F, Porporato A, Rodriguez-Iturbe I. Hydrologic controls on soil carbon and nitrogen cycles. II. A case study. Adv. Water Resour. 2003; 26: 59-70.

Davidson EA, Belk E, Boone RD. Soil water content and temperature as independent or confounded factors controlling soil respiration in a temperate mixed hardwood forest. Global Change Biol. 1998; 4: 217-227.

Del Grosso SJ, Parton WJ, Mosier AR, Ojima DS, Kulmala AE, Phongpan S. General model for $\mathrm{N}_{2} \mathrm{O}$ and $\mathrm{N}_{2}$ gas emissions from soils due to denitrification. Global Biogeochem. Су. 2000; 14: 1045-1060.

Fenn KM, Malhi Y, Morecroft MD. Soil $\mathrm{CO}_{2}$ efflux in a temperate deciduous forest: Environmental drivers and component contributions. Soil Biol. Biochem. 2010; 42: 1685-1693.

Finzi AC, Allen AS, DeLucia EH, Ellsworth DS, Schlesinger WH. Forest litter production, chemistry, and decomposition following two years of free-air $\mathrm{CO}_{2}$ enrichment. Ecology 2001; 82: 470-484.

Firestone MK, Firestone RB, Tiedje JM. Nitrous oxide from soil denitrification: Factors controlling its biological production. Science 1980; 208: 749-751.

Gee GW, Bauder JW. Particle-size analysis. In: Klute A, editor. Methods of soil analysis, part 1, Physical and mineralogical methods. ASA, Agronomy monographs 9(1), Madison, Wisconsin, USA, 1986, pp. 383-411. 
Gödde M, David MB, Christ MJ, Kaupenjohann M, Vance GF. Carbon mobilization from the forest floor under red spruce in the northeastern U.S.A. Soil Biol. Biochem. 1996; 28: 1181-1189.

Goodale CL, Aber JD. The long-term effects of land-use history on nitrogen cycling in northern hardwood forests. Ecol. Appl. 2001; 11: 253-267.

Goodwin CN, Hawkins CP, Kershner JL. Riparian restoration in the western United States: Overview and perspective. Rest. Ecol. 1997; 5: 4-14.

Gu L, Hanson PJ, Mac Post W, Liu Q. A novel approach for identifying the true temperature sensitivity from soil respiration measurements. Global Biogeochem. Cy. 2008; 22. DOI: doi:10.1029/2007GB003164.

Gu L, Post WM, King AW. Fast labile carbon turnover obscures sensitivity of heterotrophic respiration from soil to temperature: A model analysis. Global Biogeochem. Cy. 2004; 18: GB1022 1-11. DOI: 10.1029/2003GB002119.

Gurtz J, Baltensweiler A, Lang H. Spatially distributed hydrotope-based modelling of evapotranspiration and runoff in mountainous basins. Hydrol. Proc. 1999; 13: 27512768.

Hagedorn F, Martin M, Rixen C, Rusch S, Bebi P, Zürcher A, et al. Short-term responses of ecosystem carbon fluxes to experimental soil warming at the Swiss alpine treeline. Biogeochemistry 2010; 97: 7-19.

Hattermann F, Krysanova V, Wechsung F, Wattenbach M. Integrating groundwater dynamics in regional hydrological modelling. Environ. Model. Softw. 2004; 19:1039-1051.

Hefting MM, Clement J-C, Bienkowski P, Dowrick D, Guenat C, Butturini A, et al. The role of vegetation and litter in the nitrogen dynamics of riparian buffer zones in Europe. Ecol. Eng. 2005; 24: 465-482.

Heim A, Frey B. Early stage litter decomposition rates for Swiss forests. Biogeochemistry 2004; 70: 299-313.

Heinen M. Simplified denitrification models: Overview and properties. Geoderma 2006; 133: 444-463.

Hui D, Luo Y. Evaluation of soil $\mathrm{CO}_{2}$ production and transport in Duke Forest using a process-based modeling approach. Global Biogeochem. Cycles 2004; 18: GB4029.

Jenkinson DS, Coleman K. The turnover of organic carbon in subsoils. Part 2. Modelling carbon turnover. Eur. J. Soil Sci. 2008; 59: 400-413.

Kindler R, Siemens J, Kaiser K, Walmsley DC, Bernhofer C, Buchmann N, et al. Dissolved carbon leaching from soil is a crucial component of the net ecosystem carbon balance. Global Change Biol. 2011; 17: 1167-1185.

Klocker C, Kaushal S, Groffman P, Mayer P, Morgan R. Nitrogen uptake and denitrification in restored and unrestored streams in urban Maryland, USA. Aquat. Sci. 2009; 71: 411-424.

Koch O, Tscherko D, Kandeler E. Temperature sensitivity of microbial respiration, nitrogen mineralization, and potential soil enzyme activities in organic alpine soils. Global Biogeochem. Cy. 2007; 21: GB4017.

Kuzyakov Y. Review: Factors affecting rhizosphere priming effects. Journal of Plant Nutrition and Soil Science-Zeitschrift Fur Pflanzenernahrung Und Bodenkunde 2002; 165: 382-396.

Lyons J, Thimble SW, Paine LK. Grass versus trees: Maintaining riparian areas to benefit streams of central North America. J. Am. Water Resour. Assoc. 2000; 36: 919-930. 
Mander Ü, Hayakawa Y, Kuusemets V. Purification processes, ecological functions, planning and design of riparian buffer zones in agricultural watersheds. Ecol. Eng. 2005; 24 : 421-432.

Manzoni S, Porporato A. Soil carbon and nitrogen mineralization: Theory and models across scales. Soil Biol. Biochem. 2009; 41: 1355-1379.

Martin D, Chambers J. Restoration of riparian meadows degraded by livestock grazing: Above and belowground responses. Plant Ecol. 2002; 163: 77-91.

Mayer PM, Reynolds SK, Canfield TJ. Riparian buffer width, vegetative cover, and nitrogen removal effectiveness: A review of current science and regulations. US EPA, 2005, 99. 40 .

Michalzik B, Tipping E, Mulder J, Lancho JFG, Matzner E, Bryant CL, et al. Modelling the production and transport of dissolved organic carbon in forest soils. Biogeochemistry 2003; 66: 241-264.

Naiman RJ, Bilby RE, Bisson PA. Riparian ecology and management in the pacific coastal rain forest. Bioscience 2000; 50: 996-1011.

Naiman RJ, Décamps H. The ecology of interfaces: Riparian zones. Ann. Rev. Ecol. Syst. 1997; 28: 621-658.

Neff JC, Asner GP. Dissolved organic carbon in terrestrial ecosystems: Synthesis and a model. Ecosystems 2001; 4: 29-48.

Nesme T, Bellon S, Lescourret F, Senoussi R, Habib R. Are agronomic models useful for studying farmers' fertilisation practices? Agr. Syst. 2005; 83: 297-314.

Oehler F, Durand P, Bordenave P, Saadi Z, Salmon-Monviola J. Modelling denitrification at the catchment scale. Sci. Total Environ. 2009; 1726-1737.

Ollinger SV, Smith ML, Martin ME, Hallett RA, Goodale CL, Aber JD. Regional variation in foliar chemistry and cycling among forests of diverse history and composition. Ecology 2002; 83: 339-355.

Osborne LL, Kovacic DA. Riparian vegetated buffer strips in water-quality restoration and stream management. Freshwater Biol. 1993; 29: 243-258.

Paul EA, Clark FE. Soil microbiology and biochemistry. San Diego (USA): Academic Press, 1996.

Pérez MAP, Moreira-Turcq P, Gallard H, Allard T, Benedetti MF. Dissolved organic matter dynamic in the Amazon basin: Sorption by mineral surfaces. Chem. Geol. 2011; 286: 158-168.

Phillips RP, Bernhardt ES, Schlesinger WH. Elevated $\mathrm{CO}_{2}$ increases root exudation from loblolly pine (Pinus taeda) seedlings as an N-mediated response. Tree Physiol. 2009; 29: $1513-1523$.

Pietikåinen J, Pettersson M, Bååth E. Comparison of temperature effects on soil respiration and bacterial and fungal growth rates. FEMS Microbiol. Ecol. 2005; 52: 49-58.

Porporato A, D’Odorico P, Laio F, Rodriguez-Iturbe I. Hydrologic controls on soil carbon and nitrogen cycles. I. Modelling scheme. Adv. Water Resour. 2003; 26: 45-58.

Prober SM, Thiele KR, Koen LTB. Restoring ecological function in temperate grassy woodlands: Manipulating soil nutrients, exotic annuals and native perennial grasses through carbon supplements and spring burns. J. Appl. Ecol. 2005; 42: 1073-1085.

Richardson DM, Holmes PM, Esler KJ, Galatowitsch SM, Stromberg JC, Kirkman SP, et al. Riparian vegetation: Degradation, alien plant invasions, and restoration prospects. Div. Distrib. 2007; 13: 126-139. 
Rodriguez-Iturbe I, Porporato A. Ecohydrology of water-controlled ecosystems. Soil moisture and plant dynamics. Cambridge, United Kingdom: Cambridge University Press, 2004.

Rodriguez-Iturbe I, Porporato A, Ridolfi L, Isham V, Cox DR. Probabilistic modelling of water balance at a point: The role of climate, soil and vegetation. Proc. R. Soc. Lond. A 1999; 455: 3789-3805.

Rovira AD. Plant root exudates. The Botanical Review 1969; 35: 35-57.

Samaritani E, Shrestha J, Fournier B, Frossard E, Gillet F, Guenat C, et al. Heterogeneity of soil carbon pools and fluxes in a channelized and a restored floodplain section (Thur River, Switzerland). Hydrol. Earth Sys. Sci. Discuss. 2011; 8: 1059-1091.

Schijf J, Zoll AM. When dissolved is not truly dissolved - The importance of colloids in studies of metal sorption on organic matter. J. Colloid Interf. Sci. 2011; 361: 137-147.

Subke JA, Voke NR, Leronni V, Garnett MH, Ineson P. Dynamics and pathways of autotrophic and heterotrophic soil $\mathrm{CO}_{2}$ efflux revealed by forest girdling. J. Ecol. 2011; 99: 186-193.

Tietema A, Boxman AW, Bredemeier M, Emmett BA, Moldan F, Gundersen P, et al. Nitrogen saturation experiments (NITREX) in coniferous forest ecosystems in Europe: A summary of results. Environ. Pollut. 1998; 102: 433-437.

Torok K, Szili-Kovacs T, Halassy M, Toth T, Hayek Z, Paschke MW, et al. Immobilization of soil nitrogen as a possible method for the restoration of sandy grassland. Appl. Veg. Sci. 2000; 3: 7-14.

van Hees PAW, Jones DL, Finlay R, Godbold DL, Lundström US. The carbon we do not see - The impact of low molecular weight compounds on carbon dynamics and respiration in forest soils: A review. Soil Biol. Biochem. 2005; 37: 1-13.

Vogt T, Schneider P, Hahn-Woernle L, Cirpka OA. Estimation of seepage rates in a losing stream by means of fiber-optic high-resolution vertical temperature profiling. J. Hydrol. 2010; 380: 154-164.

Walthert L, Graf U, Kammer A, Luster J, Pezzotta D, Zimmermann S, et al. Determination of organic and inorganic carbon, $\delta^{13} \mathrm{C}$ and nitrogen in soils containing carbonates after acid fumigation with HCl. J. Plant Nutr. Soil Sci. 2010; 173: 207-216.

$\mathrm{Wu}$ J, Nofziger DL. Incorporating temperature effects on pesticide degradation into a management model. J. Environ. Qual. 1999; 28: 92-100.

$\mathrm{Xu}$ M, Qi Y. Soil-surface $\mathrm{CO}_{2}$ efflux and its spatial and temporal variations in a young ponderosa pine plantation in northern California. Glob. Change Biol. 2001: 7: 667677.

Young TP, Petersen DA, Clary JJ. The ecology of restoration: historical links, emerging issues and unexplored realms. Ecol. Lett. 2005; 8: 662-673. 


\section{Figure captions}

707 Figure 1. Restored Thur River site (Switzerland) and location of the monitoring point F2.

708 Figure 2. (a) Measured rainfall and computed total EVT (topsoil + root zone) for the

709 modelled period, 2008-2010; (b) measured and modelled soil temperature in the topsoil and

710 root zone; (c) computed plant activity coefficient and total litter input (topsoil + root zone).

711 Figure 3. Measured and modelled water saturation in the topsoil (a) and root zone (b).

712 Figure 4. Modelled temporal concentrations of immobile organic matter: (a) litter; (b) humus;

713 (c) biomass; (d) Measured and computed soil respiration.

714 Figure 5. Measured and modelled concentration of dissolved organic C, DOC (a) and

715 simulated dissolved organic N, DON (b), in the topsoil and root zone.

716 Figure 6. (a) Measured and modelled concentration of nitrate $\left(\mathrm{NO}_{3}{ }^{-}\right)$in the topsoil and root

717 zone; (b) measured and modelled concentration of nitrous oxide $\left(\mathrm{N}_{2} \mathrm{O}\right)$.

718 Figure 7. Influence of (a) water saturation (topsoil) and (b) soil temperature (1-m depth) over 719 soil respiration $\left(\mathrm{CO}_{2}\right)$. (c) Influence of $\mathrm{C}: \mathrm{N}$ ratio on nitrate (topsoil); and (d) influence of soil 720 temperature (1-m depth) on nitrous oxide production.

721 Figure 8. Influence of (a) soil temperature; and (b) water saturation, on dissolved organic C at 722 40-cm depth.

723 Figure 9. Modelled and experimental relationships between DOC and soil respiration $\left(\mathrm{CO}_{2}\right)$ 724 at 50-cm depth. 


\section{Tables}

727 Table 1. Soil properties measured in the mixed riparian forest (mean values \pm SDEV, 3

728 samples were considered).

\begin{tabular}{ccccc}
\hline Depth $(\mathrm{m})$ & Clay $(\%)$ & Silt $(\%)$ & Sand $(\%)$ & C org. $\left(\mathrm{g} \mathrm{kg}^{-1}\right)$ \\
\hline $0-0.2$ & $18.9 \pm 1.9$ & $55.6 \pm 3.1$ & $25.5 \pm 4.9$ & $15.2 \pm 4.3$ \\
$0.2-0.4$ & $16.1 \pm 1.3$ & $48.9 \pm 2.6$ & $34.9 \pm 3.9$ & $13.2 \pm 1.6$ \\
$0.4-0.6$ & $16.7 \pm 0.9$ & $49.3 \pm 2.8$ & $33.9 \pm 2.5$ & $10.6 \pm 2.3$ \\
$0.6-0.8$ & $18.2 \pm 3.4$ & $53.1 \pm 4.8$ & $28.7 \pm 7.6$ & $14.2 \pm 7.6$ \\
$0.8-1.0$ & $19.2 \pm 3.0$ & $53.7 \pm 6.7$ & $27.1 \pm 9.3$ & $10.5 \pm 2.2$ \\
\hline
\end{tabular}


729 Table 2. RSM validated soil and plant properties.

\begin{tabular}{|c|c|c|c|}
\hline & & \multicolumn{2}{|c|}{ Soil compartment $(i)$} \\
\hline & & Topsoil & Root zone \\
\hline Incipient stress $\left(s^{*}\right)$ & - & 0.16 & 0.15 \\
\hline Hygroscopic point $\left(s_{h}\right)$ & - & 0.02 & 0.02 \\
\hline Wilting point $\left(s_{w}\right)$ & - & 0.05 & 0.05 \\
\hline Soil porosity $(n)$ & - & 0.53 & 0.38 \\
\hline Soil thickness $(Z r)$ & $\mathrm{m}$ & 0.25 & 0.90 \\
\hline Soil tortuosity index $(d)$ & - & 1.50 & 1.50 \\
\hline Soil field capacity $\left(s_{f c}\right)$ & - & 0.50 & 0.57 \\
\hline Aquifer recharge threshold value $\left(q_{t v}\right)$ & $\mathrm{m} \mathrm{d}^{-1}$ & - & - \\
\hline Plant nitrate demand $\left(D E M^{-}\right)$ & $\mathrm{gN} \mathrm{m}^{-3} \mathrm{~d}^{-1}$ & 0.01 & 0.015 \\
\hline Plant ammonium demand $\left(D E M^{+}\right)$ & $\mathrm{gN} \mathrm{m}^{-3} \mathrm{~d}^{-1}$ & 0.06 & 0.06 \\
\hline Evapotranspiration wilting point $\left(E_{w}\right)$ & $\mathrm{m} \mathrm{d}^{-1}$ & 0.001 & 0.005 \\
\hline$G$ & - & $2.0 \times 10^{-4}$ & $2 \times 10^{-5}$ \\
\hline$L$ & - & 0.2 & 1.0 \\
\hline$f T r$ & & $4.0 \times 10^{-4}$ & $1.5 \times 10^{-4}$ \\
\hline $\begin{array}{l}\text { Maximum root exudates production rate } \\
\left(R E^{\max }\right)\end{array}$ & $\mathrm{g} \mathrm{m}^{-3} \mathrm{~d}^{-1}$ & 0.1 & 0.03 \\
\hline
\end{tabular}


731 Table 3. RSM validated soil temperature parameters.

\begin{tabular}{lcc}
\hline \multicolumn{1}{c}{ Parameter } & Units & Value \\
\hline Effective thermal diffusivity $\left(D_{h}\right)$ & $\mathrm{m}^{2} \mathrm{~d}^{-1}$ & $1.65 \times 10^{-2}$ \\
Optimal temperature & ${ }^{\circ} \mathrm{C}$ & 25 \\
Temperature sensitivity, decomposition $\left(v_{D}\right.$ QUOTE $)$ & ${ }^{\circ} \mathrm{C}$ & 0.07 \\
Temperature sensitivity, nitrification/denitrification $\left(v_{D}\right)$ & ${ }^{\circ} \mathrm{C}$ & 0.13 \\
Amplitude of the yearly temperature signal $\left(A_{l}\right)$ & ${ }^{\circ} \mathrm{C}$ & 13.21 \\
Amplitude of the daily temperature signal $\left(A_{2}\right)$ & ${ }^{\circ} \mathrm{C}$ & 1.5 \\
\end{tabular}

732 
733 Table 4. RSM calibrated biogeochemical parameters.

\begin{tabular}{|c|c|c|c|}
\hline & & \multicolumn{2}{|c|}{ Soil compartment $(i)$} \\
\hline & & Topsoil & Root zone \\
\hline C:N ratio of biomass pool $\left(C N_{b}\right)$ & - & 13.5 & 11.5 \\
\hline $\mathrm{C}: \mathrm{N}$ ratio of root exudates $\left(C N_{r}\right)$ & - & \multicolumn{2}{|c|}{12} \\
\hline C:N ratio of added litter $\left(C N_{\text {Add }}\right)$ & - & \multicolumn{2}{|c|}{15} \\
\hline Litter decomposition rate $\left(k_{l}\right)$ & $\mathrm{m}^{3} \mathrm{~d}^{-1} \mathrm{gC}^{-1}$ & $5.0 \times 10^{-6}$ & $7.75 \times 10^{-6}$ \\
\hline Humus decomposition rate $\left(k_{h}\right)$ & $\mathrm{m}^{3} \mathrm{~d}^{-1} \mathrm{gC}^{-1}$ & $3.25 \times 10^{-6}$ & $3.75 \times 10^{-6}$ \\
\hline Rate of C return to litter pool $\left(k_{d}\right)$ & $d^{-1}$ & \multicolumn{2}{|c|}{$7.5 \times 10^{-3}$} \\
\hline Litter pool mobilisation rate $\left(k_{C l}\right)$ & $d^{-1}$ & \multicolumn{2}{|c|}{$1.0 \times 10^{-6}$} \\
\hline Humus pool mobilisation rate $\left(k_{C h}\right)$ & $d^{-1}$ & \multicolumn{2}{|c|}{$0.5 \times 10^{-6}$} \\
\hline Dissolved $\mathrm{C}$ rate returning to biomass pool $\left(k_{D C}\right)$ & $\mathrm{m}^{3} \mathrm{gC}^{-1} \mathrm{~d}^{-1}$ & \multicolumn{2}{|c|}{$1.5 \times 10^{-6}$} \\
\hline Fraction of soluble humus $\left(m_{h}\right)$ & - & \multicolumn{2}{|c|}{0.20} \\
\hline Fraction of soluble litter $\left(m_{l}\right)$ & - & \multicolumn{2}{|c|}{0.40} \\
\hline Isohumic coefficient $\left(r_{h}\right)$ & - & \multicolumn{2}{|c|}{0.27} \\
\hline Respiration coefficient $\left(r_{r}\right)$ & - & \multicolumn{2}{|c|}{0.60} \\
\hline Fraction of dissolved ammonium $\left(a \_a m m\right)$ & - & \multicolumn{2}{|c|}{0.05} \\
\hline Fraction of dissolved nitrate (a_nit) & - & 1.0 & 0.5 \\
\hline Ammonium immobilisation coefficient $\left(k^{+}\right)$ & $\mathrm{m}^{3} \mathrm{~d}^{-1} \mathrm{gN}^{-1}$ & \multicolumn{2}{|c|}{0.1} \\
\hline Nitrate immobilisation coefficient $\left(k^{-}\right)$ & $\mathrm{m}^{3} \mathrm{~d}^{-1} \mathrm{gN}^{-1}$ & \multicolumn{2}{|c|}{0.1} \\
\hline Nitrification rate $\left(k_{n i t}\right)$ & $\mathrm{m}^{3} \mathrm{~d}^{-1} \mathrm{gN}^{-1}$ & 0.005 & 2.25 \\
\hline Denitrification rate $\left(k_{\text {denit }}\right)$ & $d^{-1}$ & \multicolumn{2}{|c|}{$7.5{ }_{-} 10^{-3}$} \\
\hline
\end{tabular}


735 Table 5. Measured and computed C:N ratios and $C_{\text {org }}$ concentrations for topsoil and root zone 736 layers (values in brackets indicate standard deviation).

\begin{tabular}{ccc}
\hline C:N ratios & Measured & Modelled \\
\hline Topsoil & $13.11( \pm 2.36)$ & $14.92( \pm 0.004)$ \\
Root zone & $14.02( \pm 1.83)$ & $13.95( \pm 0.003)$ \\
\hline $\boldsymbol{C}_{\text {org }}\left(\mathbf{g ~ K g ~ s o i l ~}^{-\mathbf{1}}\right)$ & Measured & Modelled \\
\hline Topsoil & $15.22( \pm 4.30)$ & $9.74( \pm 0.46)$ \\
Root zone & $12.11( \pm 3.42)$ & $9.60( \pm 0.03)$ \\
\hline
\end{tabular}

737

738 


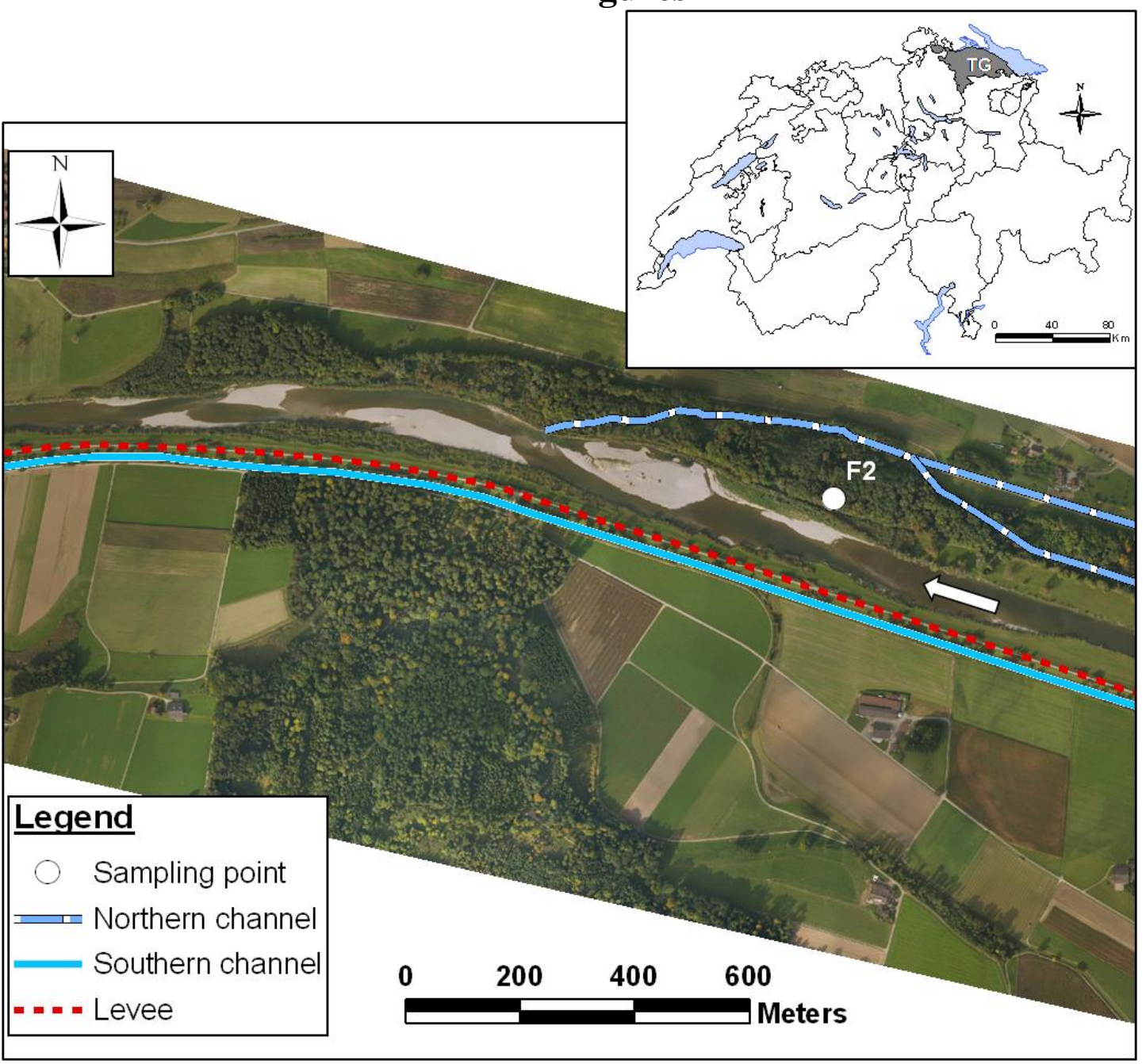

Fig. 1 

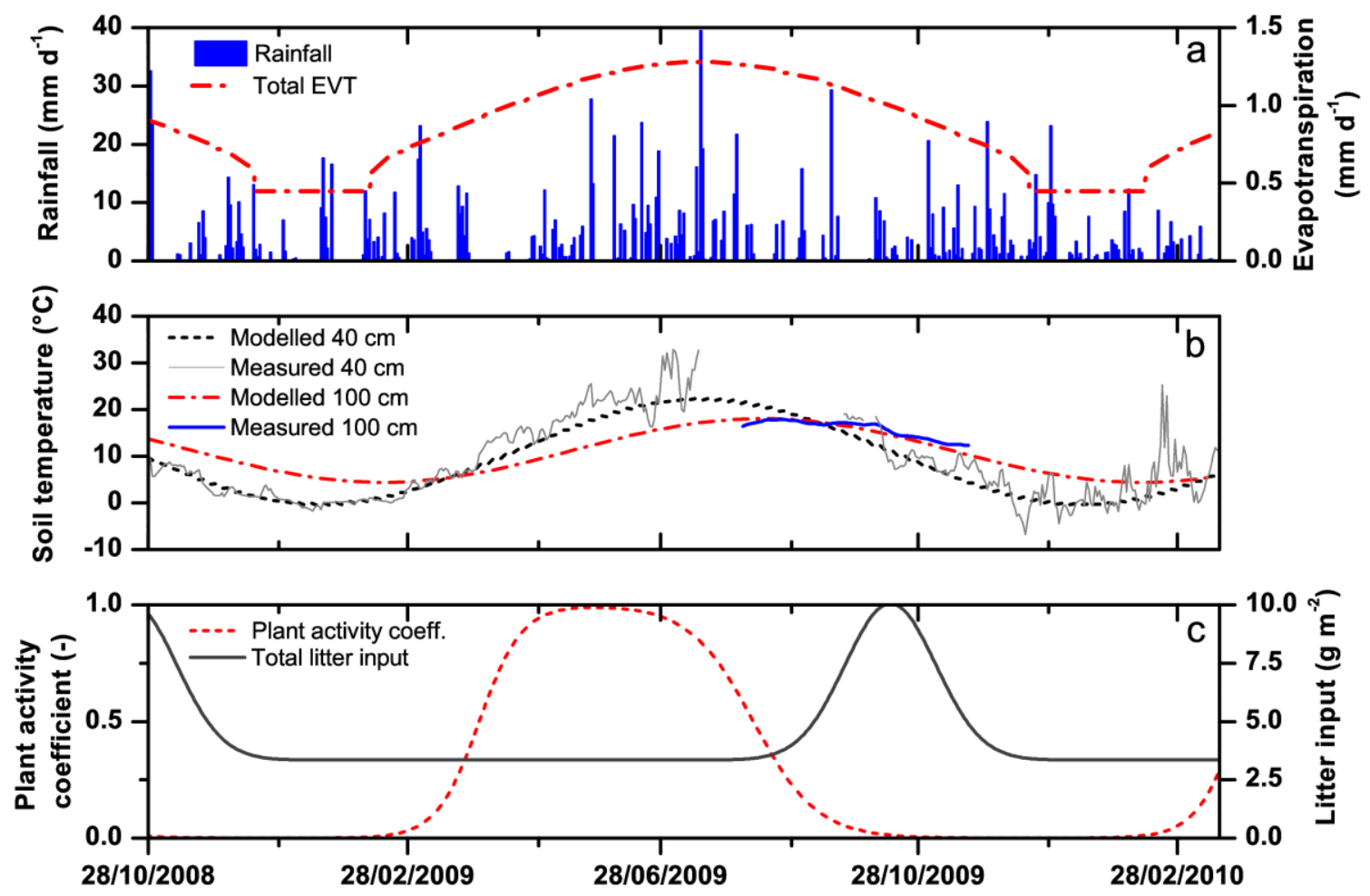

Fig. 2 


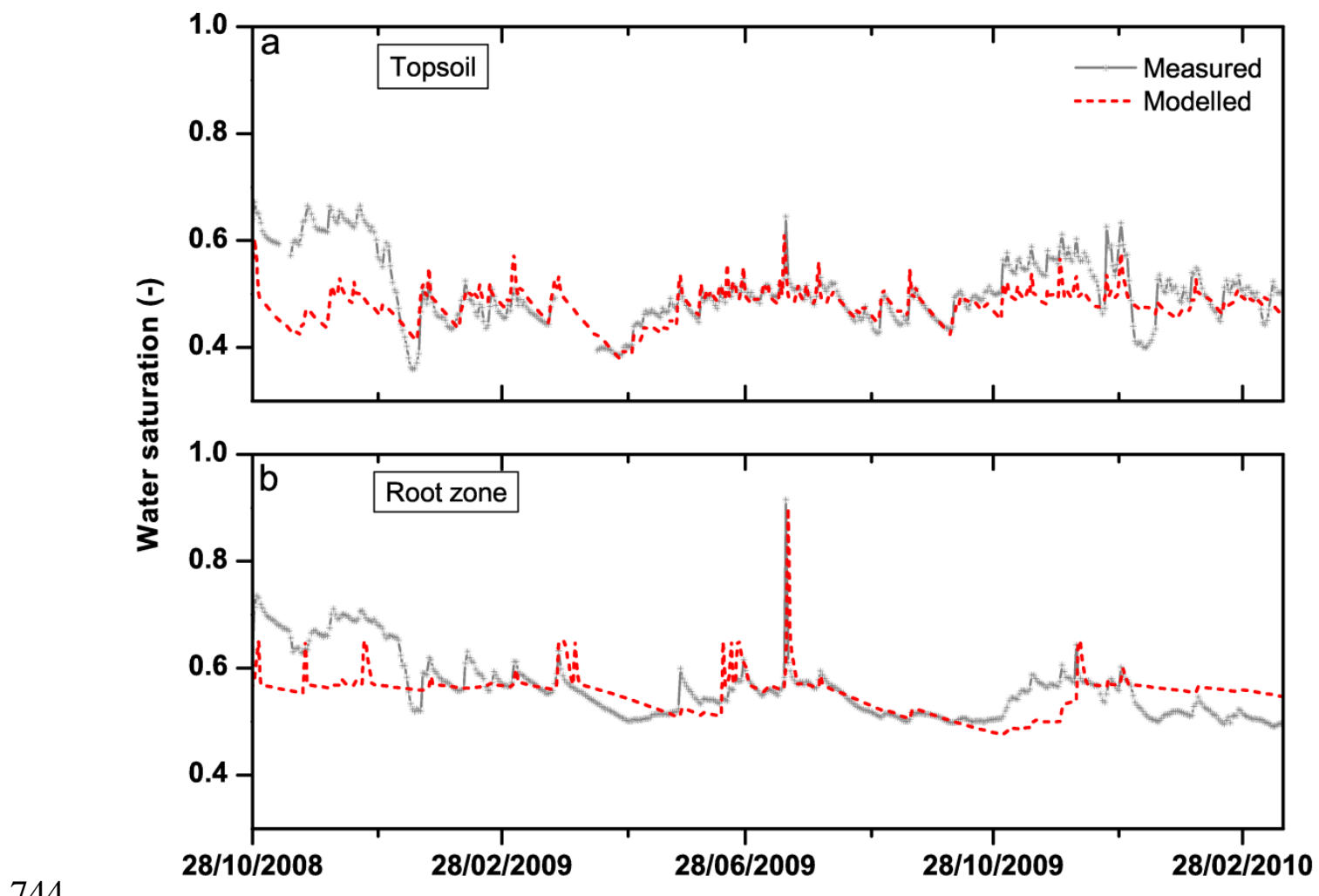

$745 \quad$ Fig. 3 

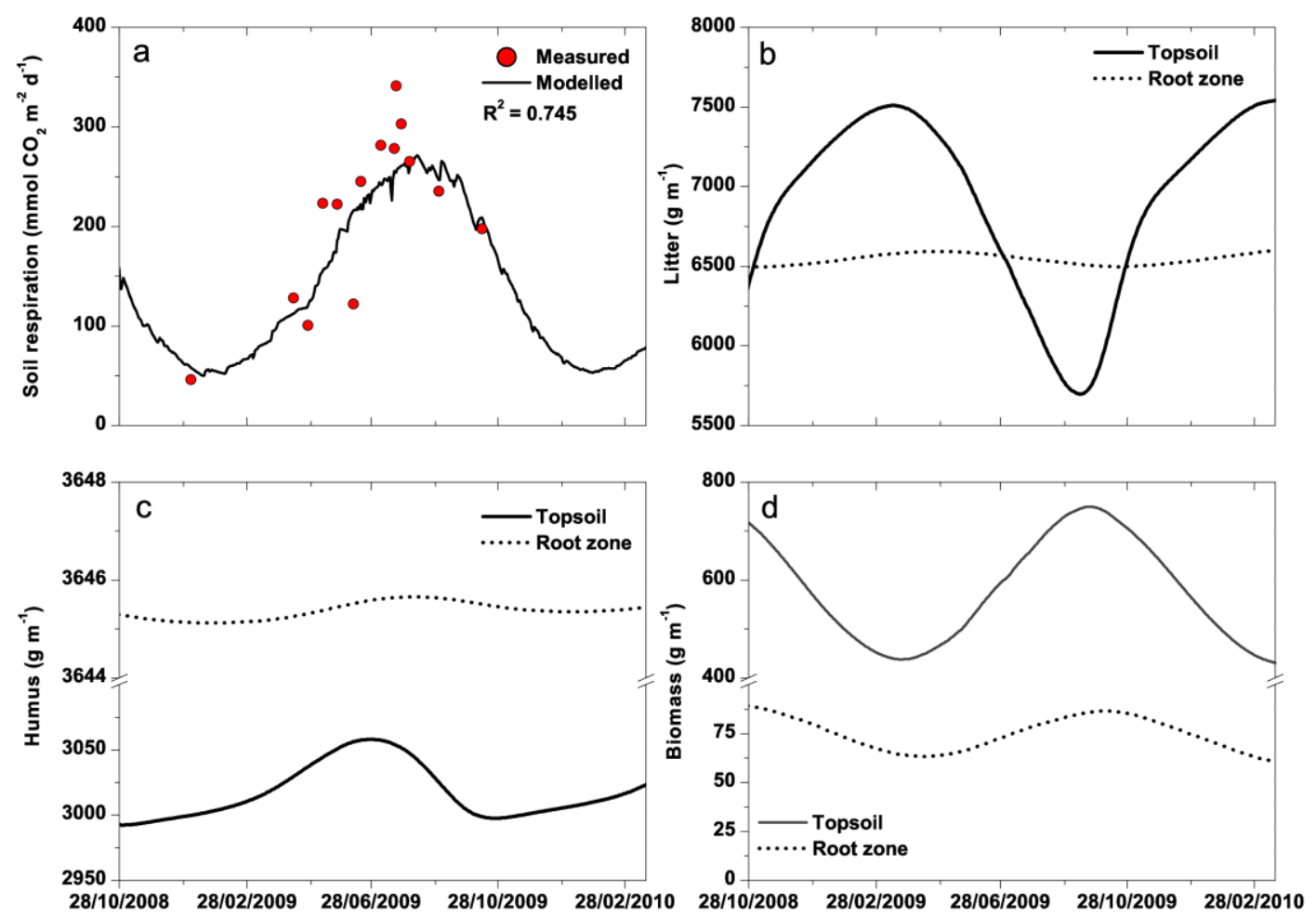

Fig. 4 

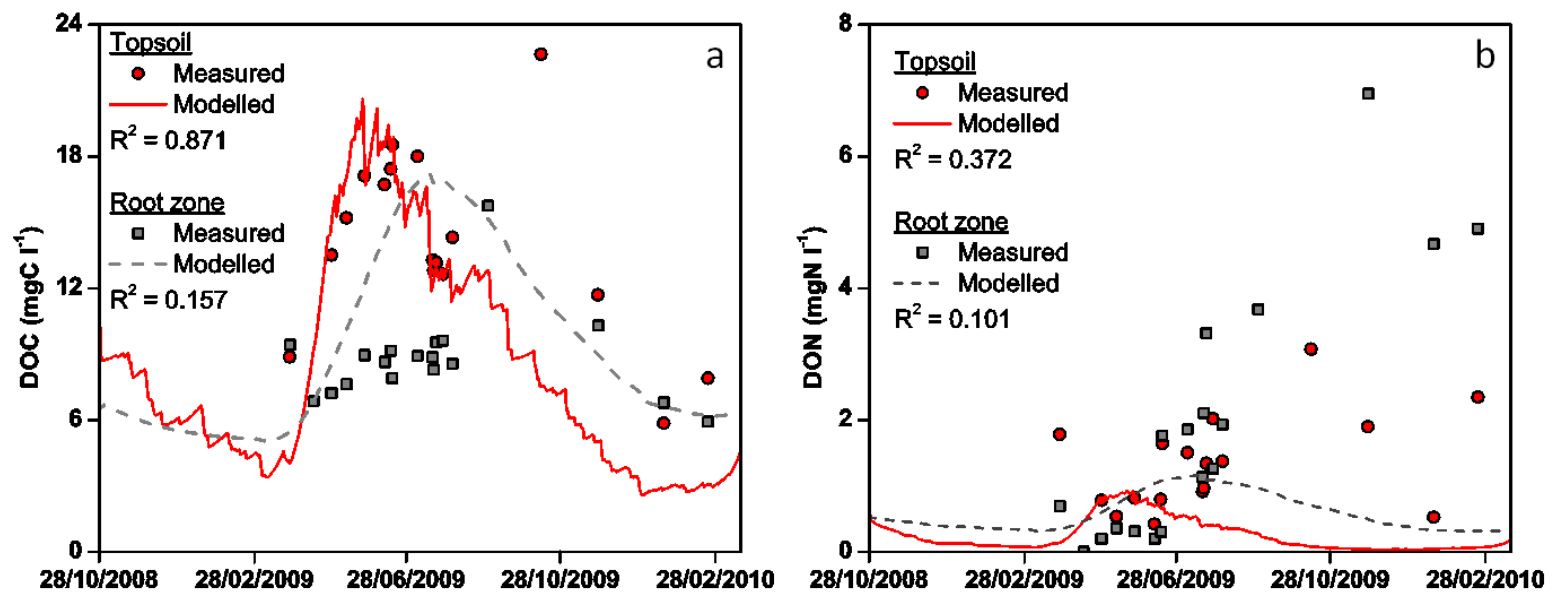

Fig. 5 

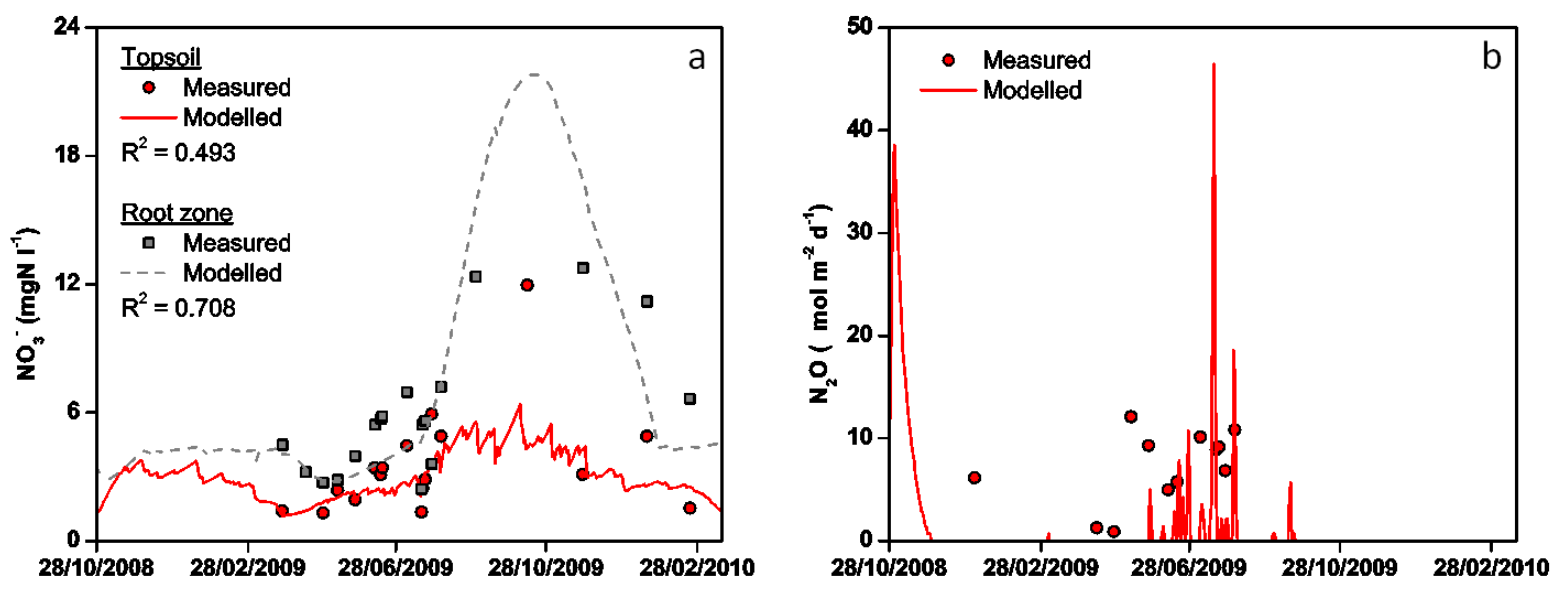

$751 \quad$ Fig. 6 

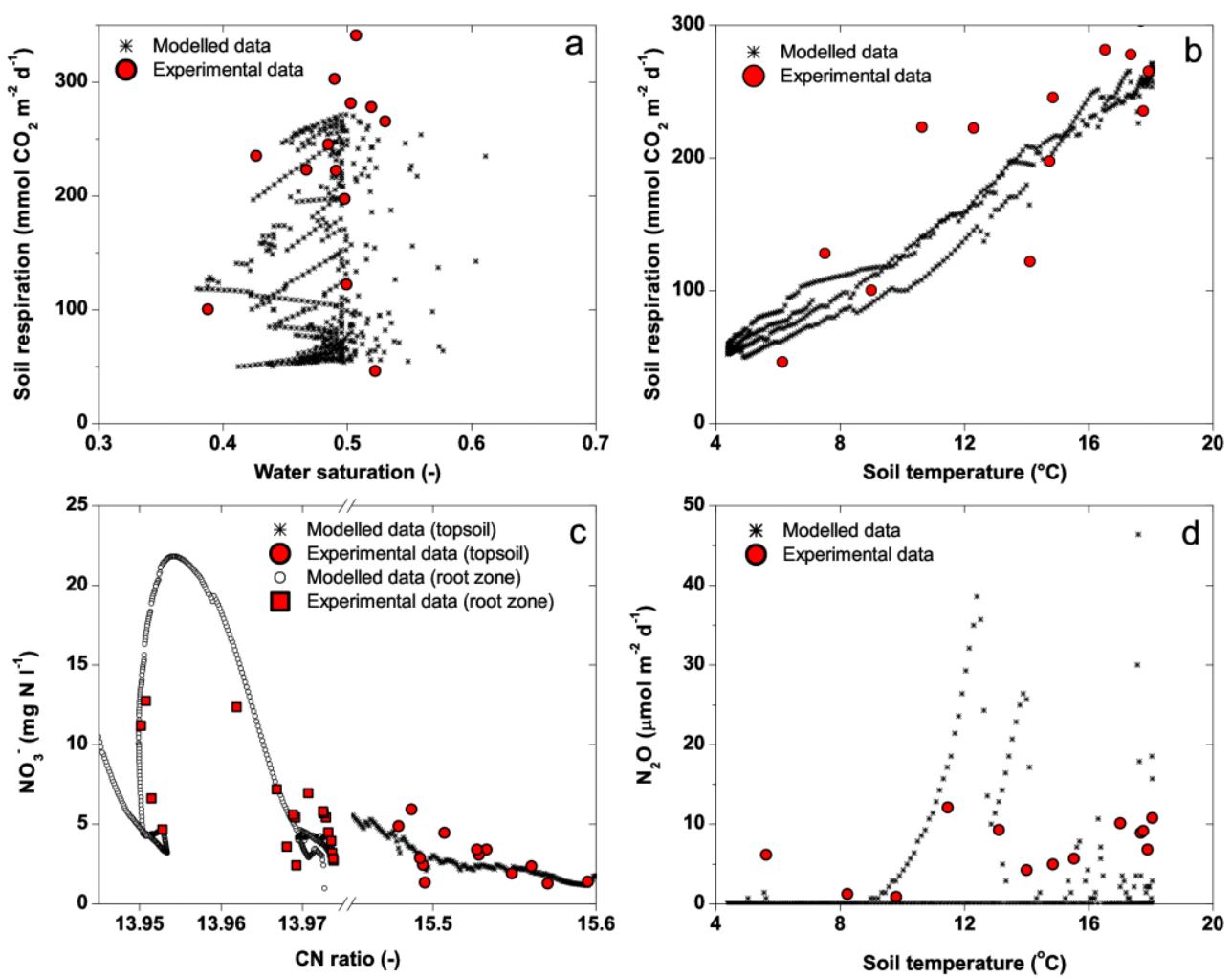

Fig. 7 

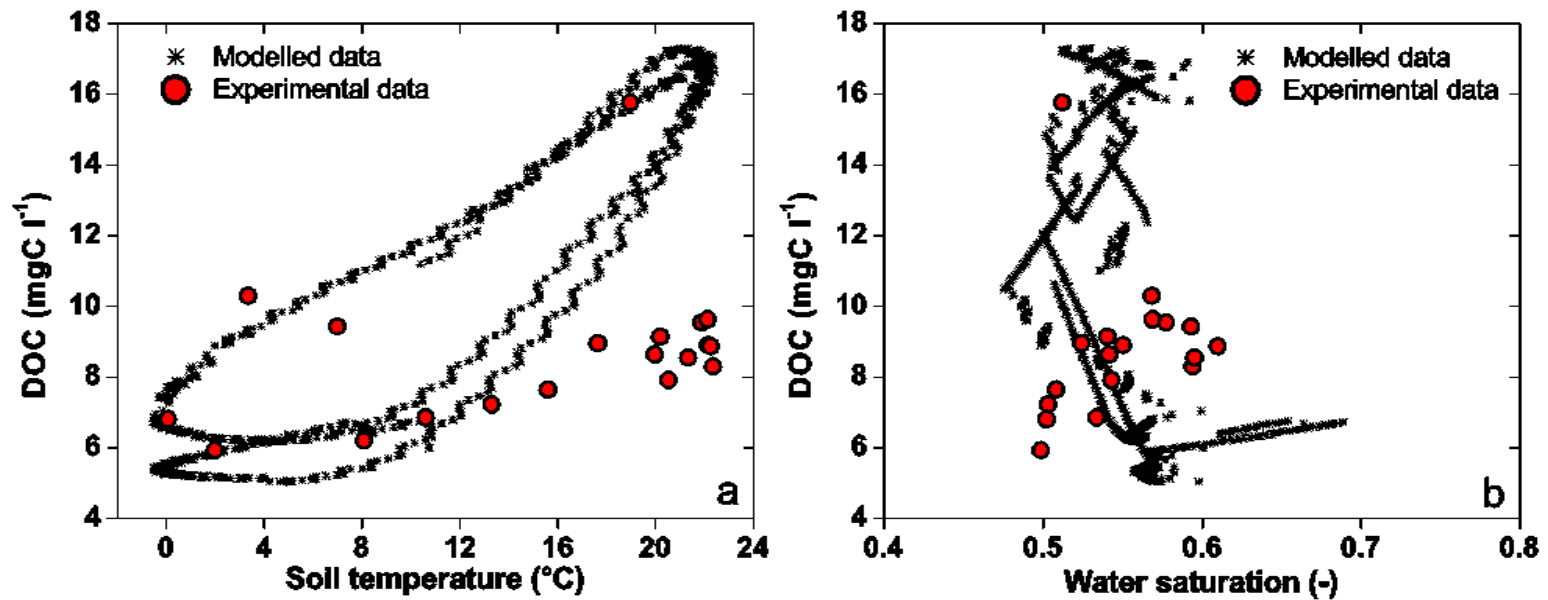

Fig. 8 


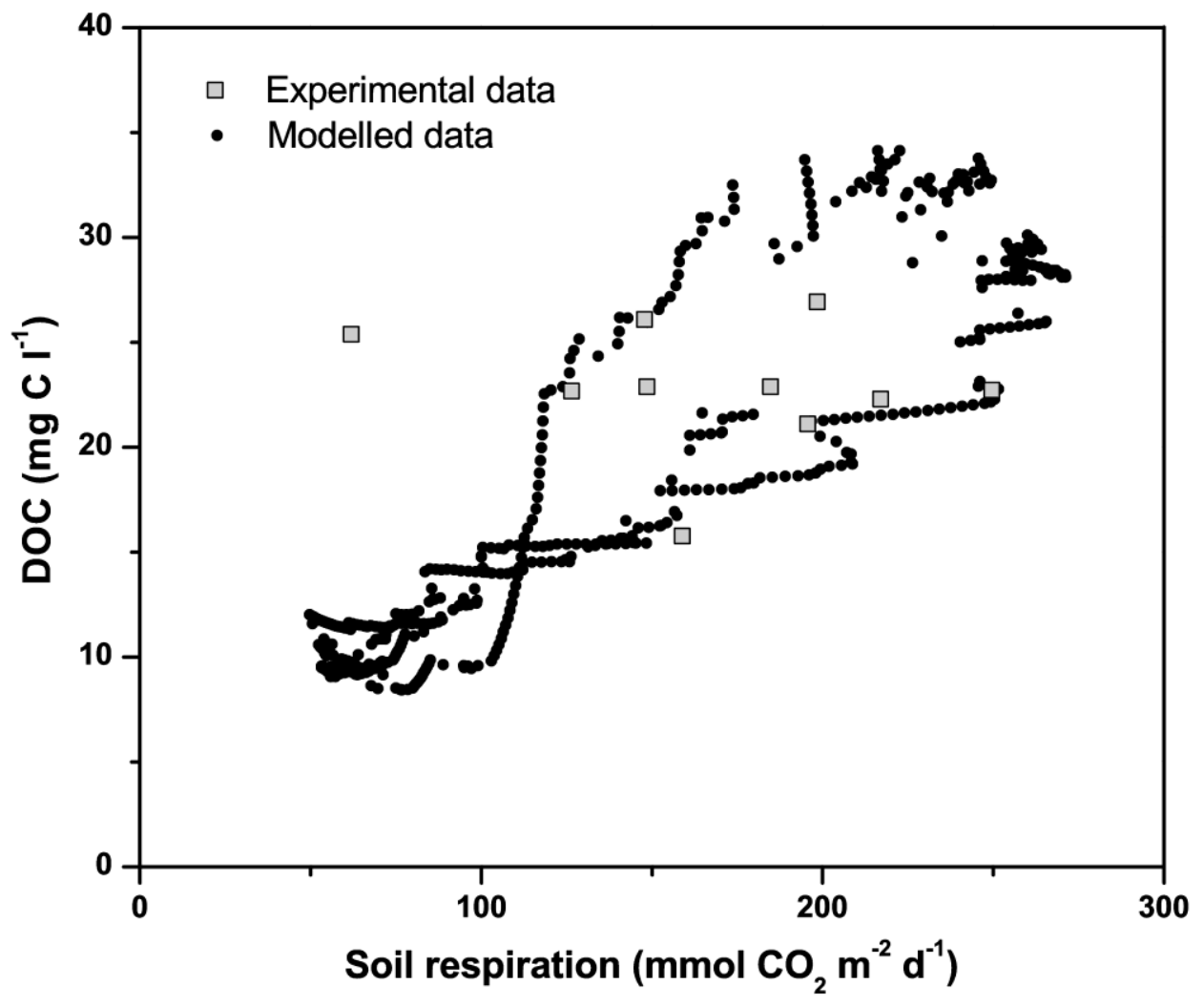

Fig. 9 